\title{
Anulación renal izquierda secundaria a tumor ureteral distal
}

Gómez Lanza E, Orsola de los Santos A, Tremps Velázquez E, Cecchini Rosell LL, Ramírez Sevilla C, Morote Robles J.

Servicio de Urología. Hospital Vall d'Hebron. Barcelona

$\mathrm{M}$ ujer de 78 años con antecedentes de ureterectomía parcial y ureterocistorrafia hace 8 años por tumor ureteral derecho distal que en urografia de control presenta anulación del riñón izquierdo. Se realiza Tomografia Computarizada visualizando atrofia renal izquierda con ureterohidronefrosis secundaria a masa ureteral distal de $3,5 \mathrm{~cm}$ de longitud que se insinúa en el meato ureteral izquierdo intravesical.

Dra. E. Gómez Lanza

E-mail: esgolan@yahoo.es

(Trabajo recibido el 21 de septiembre 2005)

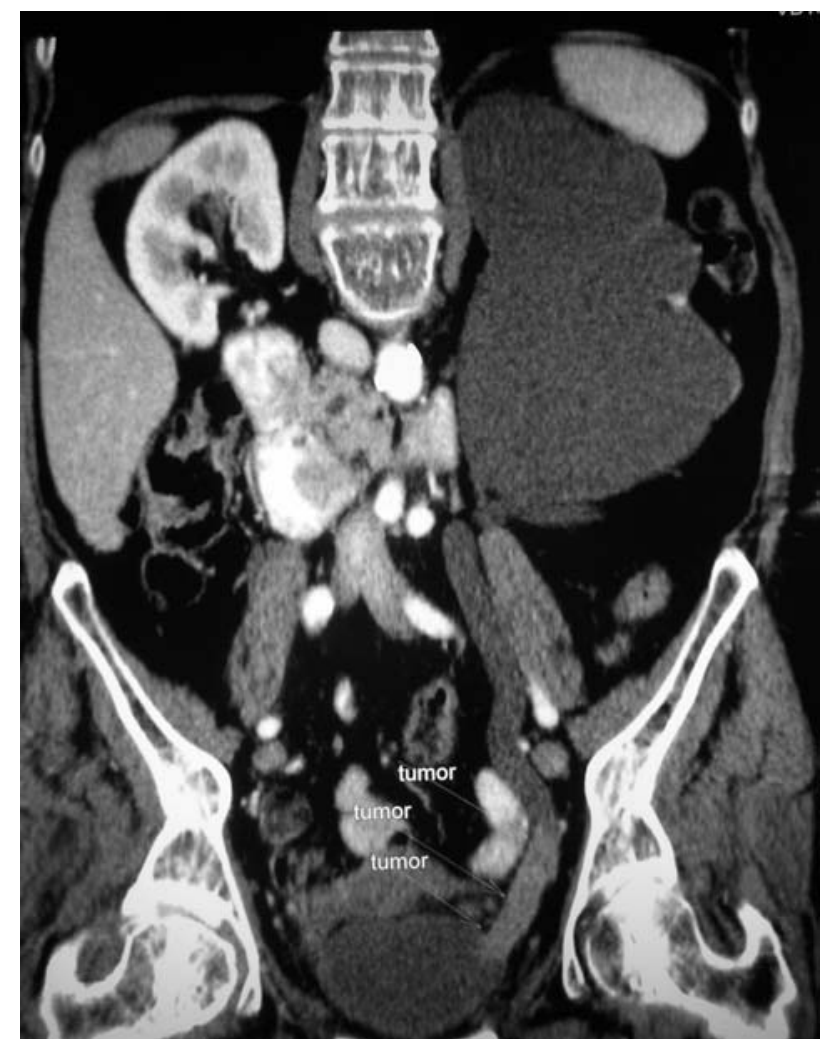

FIGURA 1

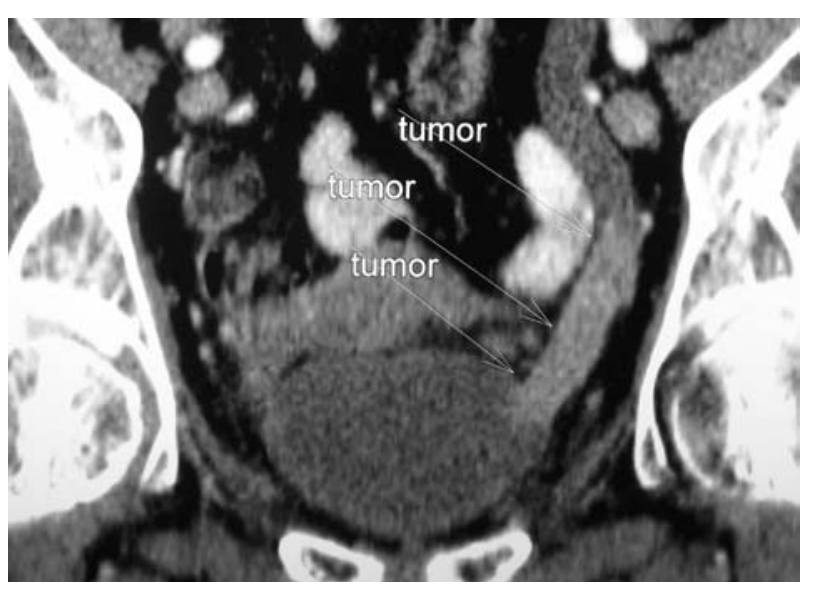

FIGURA 2 